\title{
Structural changes in leaves and roots are anatomical markers of aluminum sensitivity in sunflower ${ }^{1}$
}

\author{
Daniel da Silva de Jesus², Fabiano Machado Martins ${ }^{3}$, André Dias de Azevedo Neto ${ }^{4}$
}

\section{ABSTRACT}

Aluminum (Al) toxicity in plants evidences the importance of genotype evaluation to the identification of tolerance markers. This study aimed at evaluating the effects of aluminum stress on the relative water content, membrane damages and anatomical changes, in Al-tolerant and Al-sensitive sunflower cultivars. Sunflower plants [Catissol (Al-tolerant) and IAC-Uruguai (Al-sensitive)] were grown in nutrient solution (control) or nutrient solution containing $0.15 \mathrm{mM}$ of $\mathrm{AlCl}_{3}$ (Al-stress treatment), in a greenhouse. The experimental design was completely randomized, in a factorial arrangement consisting of four harvest times $\mathrm{x}$ two sunflower cultivars $\mathrm{x}$ two Al levels, with four replications. The results showed that Al negatively affected the absolute integrity percentage and relative water content only for the IAC-Uruguay cultivar. These results in the stressed leaves of the Al-sensitive cultivar may be due to damage in the xylem structure. In addition, the increase in leaf blade thickness and parenchyma layers, as well as lignification of root tissues, are important traits of IAC-Uruguay plants and may be used as anatomical markers of $\mathrm{Al}$ sensitivity in sunflower.

KEYWORDS: Helianthus annuus L.; relative water content; aluminum stress.

\section{INTRODUCTION}

Acid soils account for approximately $50 \%$ of arable land worldwide. In this environment, aluminum $(\mathrm{Al})$ is available in a phytotoxic form $\left(\mathrm{Al}^{3+}\right)$ and is considered the main factor to reduce plant growth (Panda et al. 2009). This restriction results from several physiological and biochemical changes in plants (Singh et al. 2015).

Roots are the plant part most susceptible to Al toxicity and its effects on shoots are usually

\section{RESUMO}

Alterações estruturais em folhas e raízes são marcadores anatômicos da sensibilidade do girassol ao alumínio

A toxicidade do alumínio (Al) em plantas demonstra que a avaliação de genótipos é importante para o reconhecimento de marcadores de tolerância. Objetivou-se avaliar os efeitos do estresse por $\mathrm{Al}$ no teor relativo de água, danos de membrana e alterações anatômicas, em variedades de girassol tolerante e sensível ao Al. Plantas de girassol [Catissol (tolerante) e IAC-Uruguai (sensível)] foram cultivadas em solução nutritiva (controle) ou solução nutritiva com 0,15 mM de $\mathrm{AlCl}_{3}$ (tratamento de estresse), em casa-de-vegetação. $\mathrm{O}$ delineamento experimental foi o inteiramente casualizado, em esquema fatorial composto por quatro épocas de colheita $\mathrm{x}$ duas variedades de girassol $\mathrm{x}$ dois níveis de $\mathrm{Al}$, com quatro repetições. Os resultados demonstraram efeitos deletérios do $\mathrm{Al}$ na porcentagem de integridade absoluta e no teor relativo de água apenas na variedade IAC-Uruguai. Estes resultados nas folhas estressadas da variedade sensível podem ter advindo dos danos na estrutura do xilema. Além disso, o aumento da espessura da lâmina foliar e nas camadas de parênquima, bem como a lignificação de tecidos da raiz, são características importantes de plantas IAC-Uruguai, podendo ser utilizadas como marcador anatômico da sensibilidade do girassol ao Al.

PALAVRAS-CHAVE: Helianthus annuus L.; teor relativo de água; estresse por alumínio.

associated with root damage (Panda et al. 2009). Aluminum causes extensive root injury, leading to poor ion and water uptake (Barceló \& Poschenrieder 2002). Some studies suggest that $A 1$ toxicity induces anatomical changes in plant tissues, reducing cell elongation and division (Gupta et al. 2013), due to changes in the cell wall characteristics. Thus, epidermis, cortex and vessels damage has been observed in several plant species (Čiamporová 2002). Given that root hydraulic conductivity is dependent on tissue radial conductivity (North \& Nobel 1996),

1. Manuscript received in May/2016 and accepted for publication in Nov./2016 (http://dx.doi.org/10.1590/1983-40632016v4641426).

2. Secretaria de Educação do Estado da Bahia, Camaçarí, BA, Brazil.E-mail: dasilva_jesus@yahoo.com.br.

3. Universidade Federal do Recôncavo da Bahia, Centro de Ciências Agrárias e Ambientais, Cruz das Almas, BA, Brazil. E-mail: fmartins@ufrb.edu.br.

4. Universidade Federal do Recôncavo da Bahia, Centro de Ciências Exatas e Tecnológicas, Cruz das Almas, BA, Brazil. E-mail: andre@ufrb.edu.br. 
damage to the tissue structure may alter the plant water content.

It has been observed that metal stress induces the lignification of root tissues (Moura et al. 2010). This anatomical change is a barrier against toxic metals, decreasing the influx into the central cylinder (Van de Mortel et al. 2008, Shu et al. 2012). On the other hand, increased root lignin levels may reduce the water uptake (Emam \& Bijanzadeh 2012), affecting cell elongation (Sasaki et al. 1996). Therefore, it has been hypothesized that the lignin content in roots is associated with $\mathrm{Al}$ stress tolerance in several plant species (Moura et al. 2010).

Aluminum also affects the plasma membrane by interacting with negative charge groups (phosphates) on the membrane surface. It has been reported that the $\mathrm{Al}^{3+}$ affinity to phosphatidylcholine is 560 times higher than $\mathrm{Ca}^{2+}$ (Akeson et al. 1989). Thus, $\mathrm{Al}$ directly affects the plasma membrane structure by displacing $\mathrm{Ca}^{2+}$ through binding to membrane phospholipids, increasing the membrane surface potential. Aluminum stress may also indirectly damage membrane polyunsaturated fatty acids by increasing the production of reactive oxygen species (Singh et al. 2015).

Sunflower is considered moderately tolerant to water and salt stress, but as an Al-sensitive plant, it cannot tolerate exchangeable $\mathrm{Al}$ levels greater than $5 \%$ (Blamey et al. 1987). However, Al tolerance varies among species and cultivars (Jesus \& Azevedo Neto 2013). As such, this study aimed at assessing the effects of $\mathrm{Al}$ stress on relative water content, membrane damage and anatomical changes in roots and leaves of Al-tolerant and Al-sensitive sunflower cultivars. These characteristics may be used as Al sensitivity markers in sunflower plants and in screenings for plant breeding programs.

\section{MATERIAL AND METHODS}

The experiment was carried out under greenhouse conditions, from July to August 2015, at the experimental unit of the Universidade Federal do Recôncavo da Bahia, Bahia State, Brazil.

Seeds of two sunflower (Helianthus annuus L.) cultivars [Catissol (Al-tolerant) and IAC-Uruguai (Al-sensitive)] were planted in trays containing vermiculite and irrigated daily with distilled water. After emergence, the seedlings were transferred to trays containing aerated, full-strength Clark's nutrient solution (Clark 1975). Ten days later, they were transplanted to $12-\mathrm{L}$ plastic pots containing the same nutrient solution (control treatment) or nutrient solution with $0.15 \mathrm{mM}$ of $\mathrm{AlCl}_{3}$ (Al-stress treatment).

The experimental design was completely randomized, in a factorial arrangement consisting of four harvest times $\mathrm{x}$ two sunflower cultivars $\mathrm{x}$ two Al levels, with four replicates. Mean values for temperature, relative humidity and photosynthetic active radiation (at noon) were $27{ }^{\circ} \mathrm{C}, 65 \%$ and $1,200 \mu \mathrm{mol} \mathrm{m} \mathrm{m}^{-2} \mathrm{~s}^{-1}$, respectively. Nutrient solutions were replaced every week and $\mathrm{pH}$ was adjusted daily to $4.5 \pm 0.2$ throughout the experiment. Plants from both treatments were grown under the same conditions for 15 days (end of the experimental period).

Absolute integrity percentage, estimated based on electrolyte leakage (Vásquez-Tello et al. 1990), and relative water content were measured in the youngest fully expanded leaf at 1, 5, 10 and 15 days after the $\mathrm{AlCl}_{3}$ application. Leaf discs were placed in closed tubes containing $10 \mathrm{~mL}$ of deionized water and incubated in the dark for $24 \mathrm{~h}$, at $8^{\circ} \mathrm{C}$. The initial electrical conductivity of the solution $\left(\mathrm{C}_{1}\right)$ was measured after equilibration at $25^{\circ} \mathrm{C}$. Samples were then boiled for $1 \mathrm{~h}$ at $100^{\circ} \mathrm{C}$ and the final electrical conductivity of heat-killed tissues $\left(\mathrm{C}_{2}\right)$ was measured after equilibration at $25{ }^{\circ} \mathrm{C}$. The absolute integrity percentage (AIP) was calculated as it follows: $\operatorname{AIP}(\%)=100-\left(\mathrm{C}_{1} \times 100 / \mathrm{C}_{2}\right)$.

Leaf relative water content (RWC) was determined as described by Barrs \& Weatherley (1962), based on the fresh, turgid and dry weight of leaf discs, using the following equation: RWC $=$ $[(\mathrm{FW}-\mathrm{DW}) /(\mathrm{TW}-\mathrm{DW})] \times 100$, where: $\mathrm{FW}, \mathrm{TW}$ and DW are respectively the fresh, turgid and dry weights of leaf discs.

Histological assessments were performed in developed roots and leaves of both sunflower cultivars. Samples were fixed in $50 \%$ FAA (37\% formaldehyde, glacial acetic acid and $50 \%$ ethanol), for $24 \mathrm{~h}$ (Johansen 1940). Plant material was exposed to vacuum desiccation during the fixation process and then transferred to $70 \%$ ethyl alcohol.

Samples were isolated and kept in $70 \%$ tertiary butyl alcohol for approximately 7 days, dehydrated in a butyl alcohol series and subsequently embedded in histological paraffin (Histosec/Merck) (Johansen 1940). Serial transverse and longitudinal sections (ca. 10-14 $\mu \mathrm{m}$ ) were cut using a rotary microtome (Leica RM2245). The sections were stained with 
$1.5 \%$ alcoholic Safranin and $1 \%$ aqueous Astra Blue (Gerlarch 1969) and mounted on permanent slides with synthetic resin (Permount/Fisher).

Photomicrographs were taken using a microscope (Olympus BX51) equipped with a digital camera (Olympus A330) and edited using the Adobe Photoshop 9.0 software. The figure scales were obtained by photographing a millimeter scale under the same optical conditions.

Averages \pm standard deviation for each treatment (cultivar x Al treatment $\mathrm{x}$ time point) were depicted in graphs by using the Sigma Plot ${ }^{\circledR} 12.0$ software.

\section{RESULTS AND DISCUSSION}

Plant tolerance of toxic elements may be associated with differences in membrane structure and function (Gupta et al. 2013). Accordingly, only small differences at 5 and 10 days were observed between the absolute integrity percentage of the control and Al-stressed plants of the Catissol cultivar (Figure 1a). On the other hand, stressed IAC-Uruguai plants exhibited a decline in absolute integrity percentage at $10(26 \%)$ and 15 days (39\%) (Figure $1 \mathrm{~b}$ ). Cell membranes are the first elements affected by plant exposure to different stresses. Aluminum acts directly by displacing $\mathrm{Ca}^{2+}$ ions, which act as bridges between membrane phospholipids, leading to membrane disruption (Akeson et al. 1989), which may cause reduced water permeability (Barceló \& Poschenrieder 2002). Additionally, Al induces rapid root inhibition, resulting in decreased ion and water uptake (Panda et al. 2009).

In this respect, similarly to membrane integrity, only the IAC-Uruguai cultivar showed an Al-induced relative water content reduction of $11 \%$ at 10 and 15 days (Figures 1c and 1d). Previous studies also report that Al stress affects the roots of IAC-Uruguai plants more significantly than those of the Catissol cultivar (Jesus \& Azevedo Neto 2013). Maintaining the membrane integrity is considered an important component of plant tolerance to $\mathrm{Al}$ stress (Gomes et al. 2011). Thus, it is likely that reduced root growth with decreased membrane integrity and water status may at least partially explain the greater sensitivity of IAC-Uruguai to Al stress, when compared to Catissol plants.

Figure 2 shows the anatomical leaf structures of both Catissol (Figures 2a and 2c) and IAC-Uruguai
(Figures $2 \mathrm{~b}$ and $2 \mathrm{~d}$ ) cultivars, under controlled conditions. In the absence of $\mathrm{Al}$, the two cultivars studied showed very similar histological features. In the midrib, the cortical region is composed of four layers of collenchyma, with irregular distribution, and parenchymal cells of varying sizes (Figures $2 \mathrm{a}$ and $2 \mathrm{~b}$ ). In both varieties, the vascular bundle of the midrib is collateral, with one central bundle and two accessory vascular bundles. The leaf blade has a uniseriate epidermis, with a thin outer periclinal wall and stomata on both sides (Figures $2 \mathrm{c}$ and $2 \mathrm{~d})$. The mesophyll is dorsiventral, with palisade parenchyma consisting of 2-4 layers of elongated cells, which occupy half of the leaf mesophyll, and spongy parenchyma with up to 8 layers of cells. The root has a uniseriate epidermis, cortex composed of several layers of irregularly-sized parenchyma cells, and exarch organization of the stele (Figures 2e and 2f).

Metal stress usually prompts changes in the leaf anatomy of several plant species (Čiamporová 2002). Accordingly, in a transverse section of the

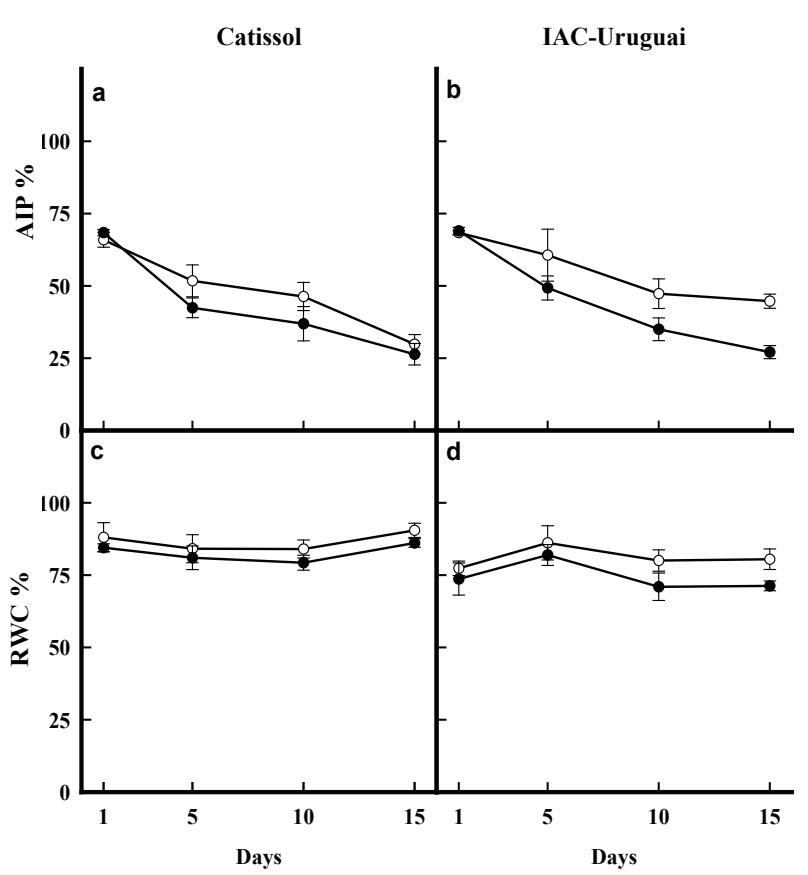

Figure 1. Absolute integrity percentage (AIP; $a$ and $b$ ) and relative water content (RWC; c and d) in leaves of Al-tolerant (Catissol; a and c) and Al-sensitive (IAC-Uruguai; $\mathrm{b}$ and d) sunflower cultivars grown under controlled $(\circ)$ or Al-stress $(\bullet)$ conditions. Plants were harvested at $1,5,10$ and 15 days after the addition of $\mathrm{Al}$ to the nutrient solution. Values represent the average \pm standard deviation. 
leaf, the differences resulting from Al tolerance and Al sensitivity were evident (Figure 3 ). The difference in midrib size is also clearly shown in Figures $3 \mathrm{a}$ and $3 \mathrm{~b}$, indicating a reduced growth in IAC-Uruguai (Al-sensitive). In IAC-Uruguai, the main vascular bundle is smaller in diameter, with fewer metaxylem elements (Figure 3d), when compared to Catisol plants (Figure 3c). The Al-sensitive cultivar also shows a disruption of the vessel elements and a decline in the size of all sieved elements (Figure 3d). This is most evident when comparing controls to stressed plants (Figures $2 \mathrm{~b}$ and $3 \mathrm{~d}$ ).
Exposure to toxic metals may alter the structure of vascular bundles in leaves (Marchiol et al. 1996, Mukhtar et al. 2013). Structural changes in the vascular bundle may also alter the water status of leaves (Gowayed \& Almaghrabi 2013), suggesting that decreased relative water content in stressed leaves of the Al-sensitive cultivar may be the result of xylem damage. In addition, a slight increase in leaf blade thickness was observed in IAC-Uruguai plants, promoted by increased cell size and cell layers in the palisade and spongy parenchyma (Figure 3f), when compared to Catissol (Figure 3e). Leaf blade
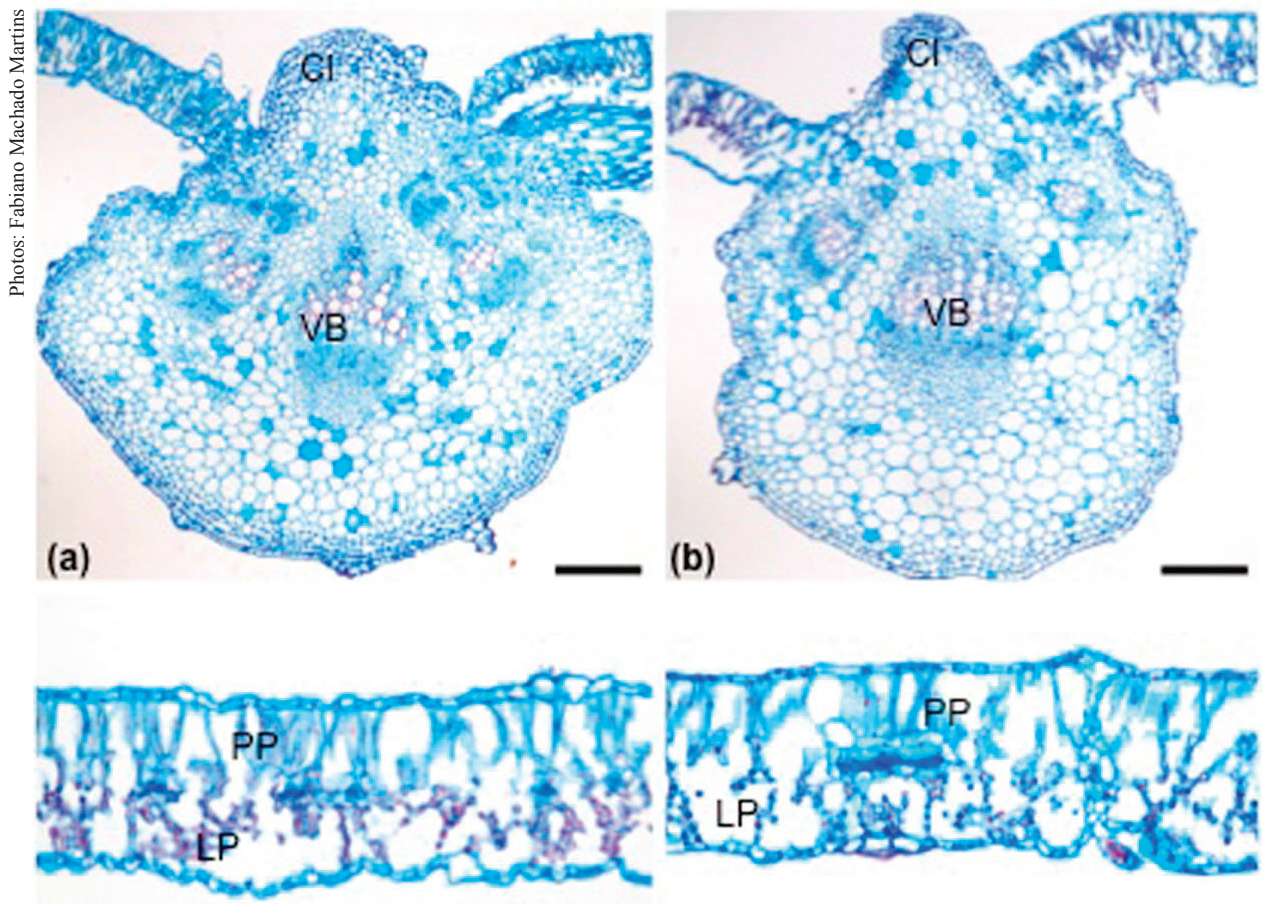

(c)

(d)
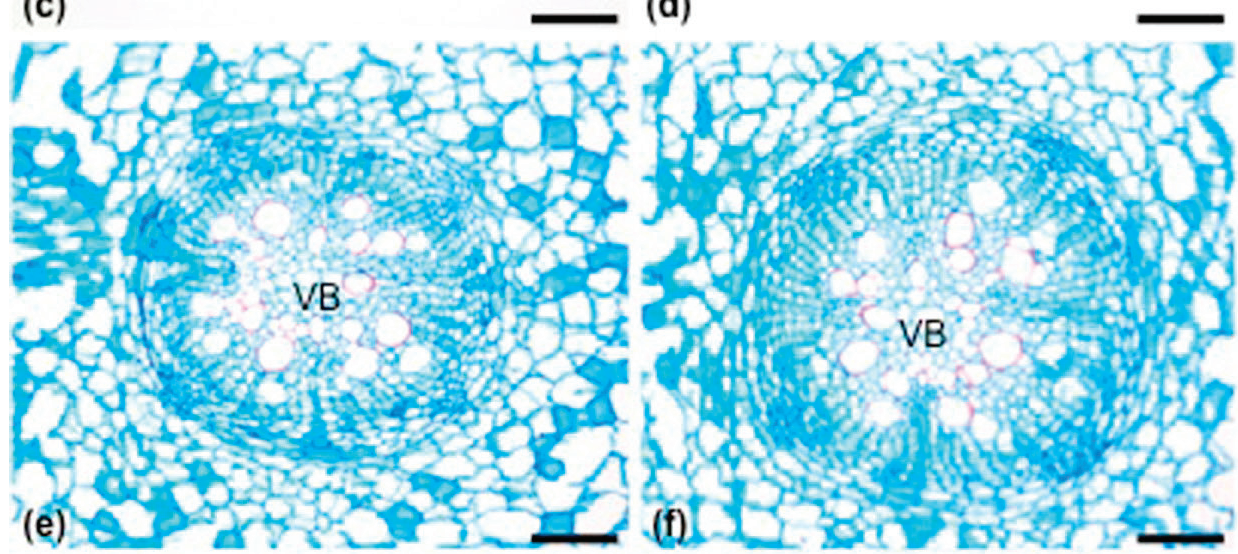

Figure 2. Cross-sections of leaf (a-d) and root (e-f) of Al-tolerant (Catissol; a, c and e) and Al-sensitive (IAC-Uruguai; b, d and f) sunflower cultivars grown under controlled conditions, showing similarities between tissues and anatomical structures in both varieties. VB: vascular bundle; $\mathrm{Cl}$ : collenchyma; PP: palisade parenchyma; LP: lacunose parenchyma. Scale: $170 \mu \mathrm{m}$ (a-b); $60 \mu \mathrm{m}$ (c-f). 
thickening has been reported under metal stress, due to an increase in intercellular spaces and/or in the number of parenchymatic cells (Čiamporová 2002). These results indicate that changes in leaf anatomy may be used as a marker of $\mathrm{Al}$ sensitivity in sunflower.
It has been suggested that the maintenance of the root integrity of peripheral tissue is associated with Al-stress tolerance (Alvarez et al. 2012). Accordingly, the results showed that the root epidermis and cortex were significantly affected by
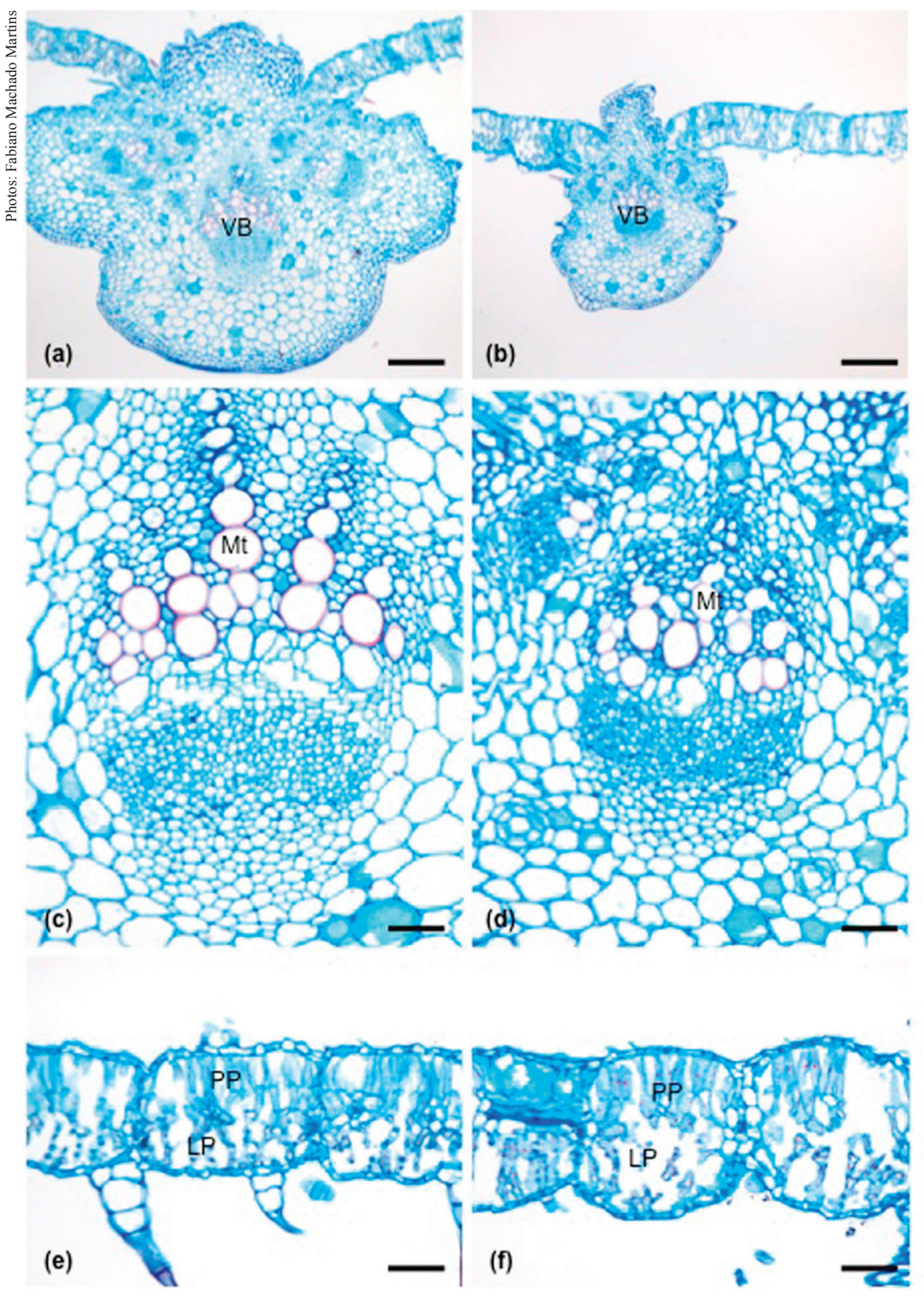

Figure 3. Cross sections of leaves of Al-tolerant (Catissol; $a, c$ and e) and Al-sensitive (IAC-Uruguai; b, $d$ and f) sunflower cultivars grown under stress conditions ( $0.15 \mathrm{mM}$ of Al). a-b: differences in midrib thickness between the two cultivars; c-d: normal vascular bundles in Catissol and apparent disarray of the vessel elements in IAC-Uruguai; e-f: increase in intercellular spaces may be observed in IAC-Uruguai; VB: vascular bundle; Mt: metaxylem; PP: palisade parenchyma; LP: lacunose parenchyma. Scale: $170 \mu \mathrm{m}(\mathrm{a}-\mathrm{b}) ; 60 \mu \mathrm{m}$ (c-f). 
Al stress in the Al-sensitive plants (Figures 4b, 4d and 4f). Both cultivars showed partial destruction of the epidermis (Figures $4 \mathrm{a}$ and $4 \mathrm{~b}$ ). However, damage was more conspicuous in IAC-Uruguai (Figure 4b). This effect may be due to the fact that roots are the first organ to be exposed to Al (Čiamporová 2002). In IAC-Uruguai, the harmful effects of $\mathrm{Al}$ reach the inner layers of the cortex, with cell disintegration and the presence of enlarged cells. Increased cell size may be considered an additional factor exerting pressure on the epidermal cell layer, leading to rupture (Čiamporová 2002).
Significant differences were also observed between the Catisol and IAC-Uruguai cultivars in the vascular cylinder. In Catisol plants, the endodermis and pericycle are easily observed (Figure 4e), but are not evident in IAC-Uruguai (Figure 4f). Cells undergoing cell division may be seen in the pericycle region, indicating the formation of scar tissue (Figure 4f). In Catisol, the vascular cambium exhibits normal activity with the formation of secondary driving elements, in contrast with IAC-Uruguai, which shows no continuous cambium and complete disorientation of sieve tube elements (Figure 4f).
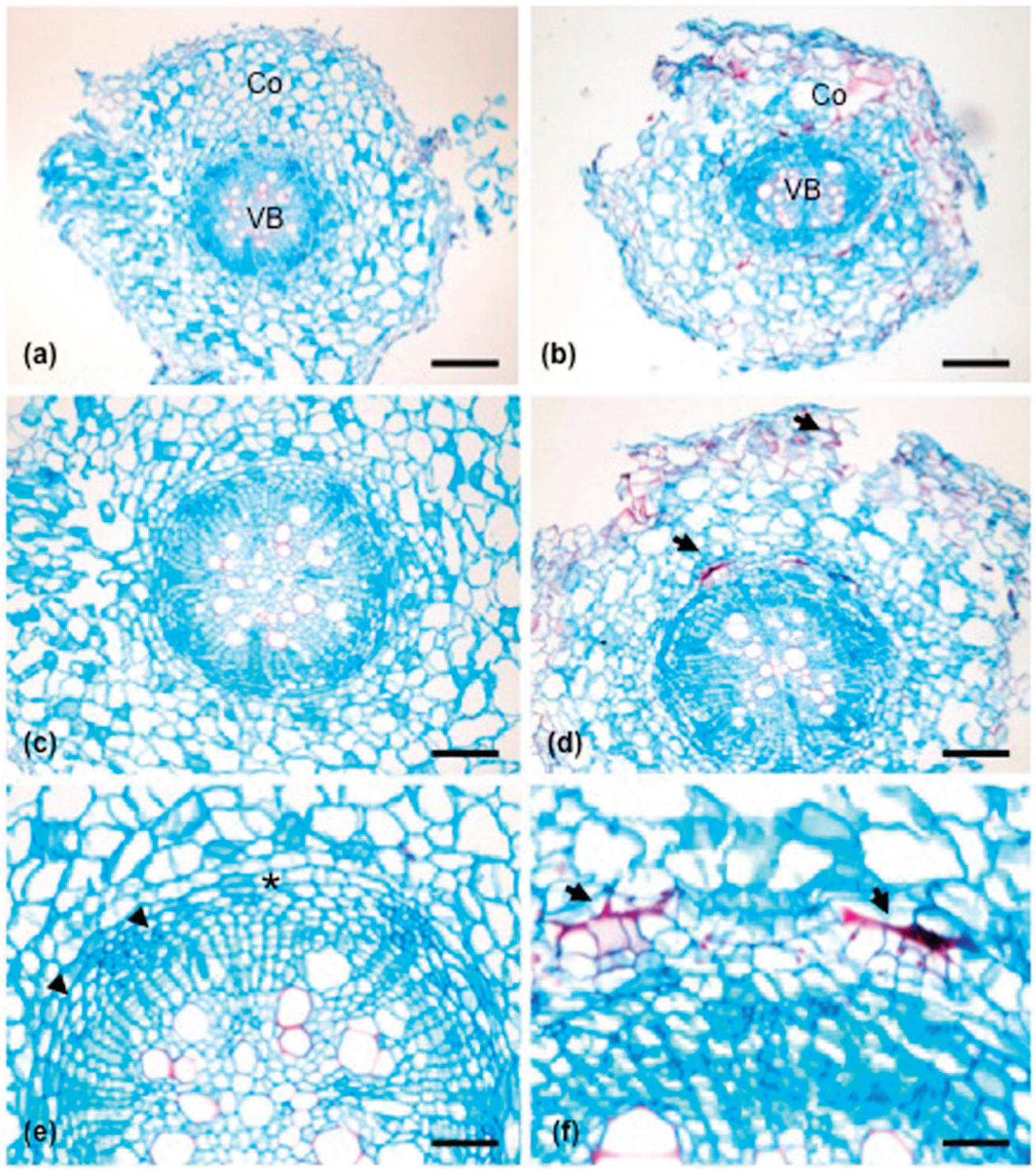

Figure 4. Cross-sections of roots of the Al-tolerant (Catissol; $a$, c and e) and Al-sensitive (IAC-Uruguai; b, d and f) sunflower cultivars grown under stress conditions $(0.15 \mathrm{mM}$ of Al). a-b: overview of roots; $\mathrm{c}-\mathrm{d}$ : tissue integrity in Catissol and cortex damage in IAC-Uruguai $(\rightarrow$; e-f: regular tissue distribution in Catissol roots and cell damage and phenolic compound deposition in IAC-Uruguai $(\rightarrow)$; Co: cortex; VB: vascular bundle; *: endodermis; $>$ : pericycle. Scale: $170 \mu \mathrm{m}(\mathrm{a}-\mathrm{b}) ; 60 \mu \mathrm{m}(\mathrm{c}-\mathrm{f})$. 
In contrast to Catissol plants (Figures $4 \mathrm{a}, 4 \mathrm{c}$ and $4 \mathrm{e}$ ), the Al-sensitive cultivar showed cortical parenchyma cells near the vascular cylinder with irregular arrangement and formation of intercellular spaces. Some cortical parenchyma cells, particularly those located close to the endodermis, exhibited safranin staining in the cell wall (Figures 4b, 4d and 4f). The use of safranin colorants enables the visualization of lignified cell walls in tissues, such as vessel elements (stained red) (Srebotnik \& Messner 1994, Doğu \& Grabner 2010). The Al-sensitive IAC-Uruguai plants showed an increase in the number of root cells with highly lignified cell walls. In some cases, lignification may be beneficial, forming a physical barrier against toxic metals (Van de Mortel et al. 2008). Alternatively, in a number of plant species, increased lignification occurs in response to mechanical damage in tissues, such as rupture of epidermal cell layer (Moura et al. 2010).

The Al content inside root cells was not measured. As such, we speculate that the lignin deposition in the cell walls of the Al-sensitive IAC-Uruguai cultivar was the result of the Al-induced mechanical damage in root cells. Lignification in the root elongation zone has also been reported in Al-stressed wheat plants (Sasaki et al. 1996). The authors demonstrated that lignification was dosedependent and directly related to reduced root growth. Similarly, Wu et al. (2014) reported that lignification may be considered an indicative of sensitivity to Al-stress. Our findings showing that the lignin deposition in root cell walls was observed only in the Al-sensitive cultivar support this hypothesis and suggest that Al-induced lignification may be an important trait of $\mathrm{Al}$ sensitivity in sunflower.

\section{CONCLUSIONS}

1. Aluminum stress alters the leaf structure and water status (absolute integrity percentage and relative water content) of sunflower plants;

2. The increase in leaf blade thickness and parenchyma layers observed in Al-stressed IAC-Uruguay plants indicates that these changes in leaf anatomy may be used as an anatomical marker of Al sensitivity in sunflower leaves;

3. Aluminum-induced root lignification may also be an important trait of Al sensitivity in sunflower roots.

\section{ACKNOWLEDGMENTS}

The authors thank the Conselho Nacional de Desenvolvimento Científico e Tecnológico (CNPq) for the financial support over the years.

\section{REFERENCES}

AKESON, M. A.; MUNNS, D. N.; BURAU, R. G. Adsorption of $\mathrm{Al}^{3+}$ to phosphatidylcholine vesicles. Biochimica et Biophysica Acta, v. 986, n. 1, p. 33-40, 1989.

ALVAREZ, I. et al. Morphological and cellular changes in rice roots (Oryza sativa L.) caused by Al stress. Botanical Studies, v. 53, n. 1, p. 67-73, 2012.

BARCELÓ, J.; POSCHENRIEDER, C. Fast root growth responses, root exudates, and internal detoxification as clues to the mechanisms of aluminum toxicity and resistance: a review. Environmental and Experimental Botany, v. 48, n. 1, p. 75-92, 2002.

BARRS, H. D.; WEATHERLEY, P. E. A re-examination of the relative turgidity technique for estimating water deficit in leaves. Australian Journal of Biological Science, v. 15, n. 3, p. 413-428, 1962.

BLAMEY, F. P. C.; EDWARDS, D. G.; ASHER, C. J. Nutritional disorders of sunflower. Brisbane: University of Queensland, 1987.

ČIAMPOROVÁ, M. Morphological and structural responses of plant roots to aluminum at organ, tissue, and cellular levels. Biologia Plantarum, v. 45, n. 2, p. 161171, 2002.

CLARK, J. Characterization of phosphatase of intact maize roots. Journal of Agricultural Food Chemistry, v. 23, n. 3, p. 458-460, 1975.

DOĞU, A. D.; GRABNER, M. A staining method for determining severity of tension wood. Turkish Journal of Agricultural and Forest, v. 34, n. 5, p. 381-392, 2010.

EMAM, Y.; BIJANZADEH, E. Water uptake and hydraulic conductivity of seminal and adventitious roots of five wheat cultivars at early growth stage. Journal of Agricultural Science and Technology, v. 14, supplementary issue, p. 1605-1616, 2012.

GERLARCH, D. Botanische mikrotechnik: eine einführung. Stuttgart: Georg Thieme, 1969.

GOMES, M. P. et al. Ecophysiological and anatomical changes due to uptake and accumulation of heavy metal in Brachiaria decumbens. Scientia Agricola, v. 68, n. 5, p. 566-573, 2011.

GOWAYED, S. M. H.; ALMAGHRABI, O. A. Effect of copper and cadmium on germination and anatomical 
structure of leaf and root seedling in maize (Zea mays L). Australian Journal of Basic and Applied Sciences, v. 7, n. 1, p. 548-555, 2013.

GUPTA, N.; GAURAV, S. S.; KUMAR, A. Molecular basis of aluminum toxicity in plants: a review. American Journal of Plant Sciences, v. 4, n. 12C, p. 21-37, 2013.

JESUS, D. da S. de; AZEVEDO NETO, A. D. de. Aluminum tolerance in sunflower plants is associated with phosphorus content in the roots. Communication in Soil Science and Plant Analysis, v. 44, n. 22, p. 34233430, 2013.

JOHANSEN, D. A. Plant microtechnique. New York: McGraw Hill, 1940.

MARCHIOL, L. et al. Physiological responses of two soybean cultivars to cadmium. Journal of Environmental Quality, v. 25, n. 3, p. 562-566, 1996.

MOURA, J. C. M. S. et al. Abiotic and biotic stresses and changes in the lignin. Journal of Integrative Plant Biology, v. 52, n. 4, p. 360-376, 2010.

MUKHTAR, N. et al. Modifications in stomatal structure and function in Cenchrus ciliaris L. and Cynodon dactylon (L.) pers. in response to cadmium stress. Pakistan Journal of Botany, v. 45, n. 2, p. 351-357, 2013.

NORTH, G. B.; NOBEL, P. Radial hydraulic conductivity of individual root tissues of Opuntia ficus-indica (L.) Miller as soil moisture varies. Annals of Botany, v. 77, n. 2, p. 133-142, 1996.

PANDA, S. K.; BALUSKA, F.; MATSUMOTO, H. Aluminum stress signaling in plants. Plant Signaling \& Behavior, v. 4, n. 7, p. 592-597, 2009.
SASAKI, M.; YAMAMOTO, Y.; MATSUMOTO, $\mathrm{H}$. Lignin deposition induced by aluminum in wheat (Triticum aestivum) roots. Physiology Plantarum, v. 96, n. 2, p. 193-198, 1996.

$\mathrm{SHU}, \mathrm{X}$. et al. Effect of $\mathrm{Pb}$ toxicity on leaf growth, antioxidant enzyme activities, and photosynthesis in cuttings and seedlings of Jatropha curcas L. Environmental Science and Pollution Research International, v. 19, n. 3, p. 893-902, 2012.

SINGH, D. et al. Physiological and biochemical characteristics of Vigna species for Al stress tolerance. Acta Phyisiologiae Plantarum, v. 37, n. 87, p. 1-13, 2015.

SREBOTNIK, E.; MESSNER, K. A simple method that uses differential staining and light microscopy to assess the selectivity of wood delignification by white rot fungi. Applied and Environmental Microbiology, v. 60, n. 4, p. 1383-1386, 1994.

VAN DE MORTEL, J. et al. Expression differences for genes involved in lignin, glutathione and sulphate metabolism in response to cadmium in Arabidopsis thaliana and the related $\mathrm{Zn} / \mathrm{Cd}$-hyperaccumulator Thlaspi caerulescens. Plant, Cell \& Environment, v. 31, n. 3, p. 301-324, 2008.

VÁSQUEZ-TELLO, A. et al. Electrolyte and Pi leakages and soluble sugar content as physiological tests for screening resistance to water stress in Phaseolus and Vigna species. Journal of Experimental Botany, v. 41, n. 7, p. 827-832, 1990.

WU, D. et al. Alleviation of aluminum-induced cell rigidity by overexpression of OSPIN2 in rice roots. Journal of Experimental Botany, v. 65, n. 18, p. 5305-5315, 2014. 